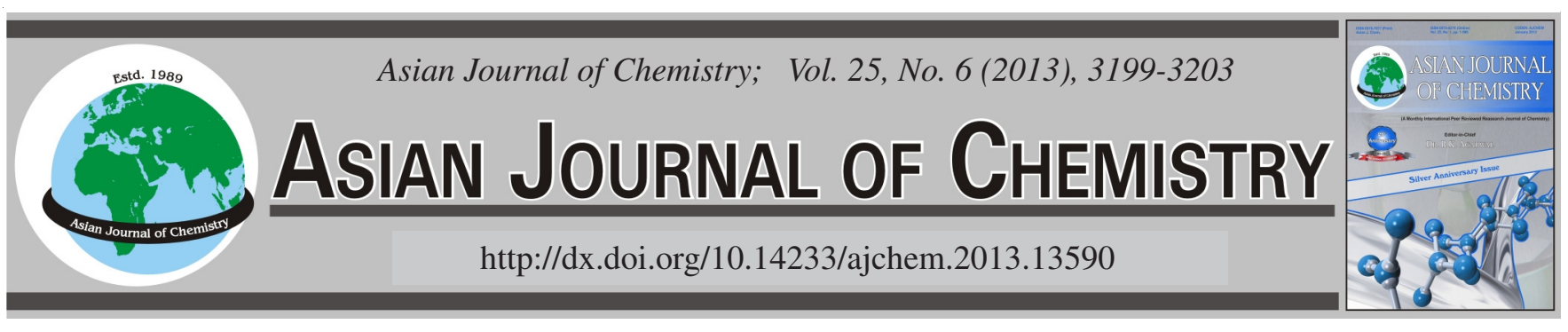

\title{
Study of Physico-Chemical Characteristics of Surface Water Using Regression Analysis of Cauvery River and Its Tributaries in Tamilnadu, India
}

\begin{abstract}
S. $\operatorname{HEMA}^{1, *}$ and T. SUBRAMANI ${ }^{2}$
${ }^{1}$ Department of Civil Engineering, Kongu Engineering College, Erode-638 052, India

${ }^{2}$ Department of Geology, Anna University, Chennai-600 025, India

*Corresponding author: E-mail: shema_er@yahoo.com; geosubramani@yahoo.com

(Received: 14 February 2012;

Accepted: 14 December 2012)

AJC-12547

Cauvery river is one of the important rivers of peninsular India. Because of its importance in culture and dense population along its banks, it is facing a lot of anthropogenic influences. In this study, surface water samples were collected from 50 stations in the river and its tributaries and analyzed for its physicochemical characteristics in February 2009 and October 2009 in order to understand the sources of water pollution and the evolution of water quality. The results indicate a significant variation among the water quality parameters in the river which was also influenced by the quality of water from its tributaries. Seasonal variations were observed in the river, which was due to catchment characteristics and point or nonpoint sources of pollution. Pearson correlation used to determine the correlation between the water quality parameters was found to be highly correlated. The regression equations developed to estimate the parameters responsible for water quality variations are found to be useful for assessment of missing data in order to get better information about the quality of surface water.

Key Words: Cauvery river, Water quality, Correlation, Regression analysis.
\end{abstract}

\section{INTRODUCTION}

Urbanization and industrialization have led to the increased demand for water and at the same time have posed a threat to its availability in good quality. Rivers serve as the main source of freshwater for all human activities. The quantity and quality of the river water is greatly influenced by anthropogenic activities $^{1}$. In India, the problem of water pollution has reached an alarming situation and about $70 \%$ of rivers in India are polluted $^{2}$ and there has been increased emphasis on deterioration of water quality of Indian rivers ${ }^{3}$. Studies have shown the presence of positive correlation between industrialization and contamination of surface water bodies by heavy metals ${ }^{4}$. In India, compared to northern rivers, southern rivers are less studied, may be due to their smaller size and discharge and most of the peninsular Indian rivers are highly seasonal and shorter ${ }^{5}$. Cauvery river has been the focus of attention due to impacts caused by the improper disposal of industrial wastes recently. Several researches have indicated the presence of high level of pollutants in the river making the water unsuitable for drinking and industrial usage as well ${ }^{6}$. Health problems were evident in the river basin from a survey ${ }^{7}$ and surface water is highly polluted by the discharge of untreated industrial effluents and municipal sewage ${ }^{8}$.
The discharges from major industries, Sago and dyeing units are polluting the river to a greater extent ${ }^{9}$. It is crucial to ascertain the behaviour and variation of the constituents and to study the influence of sources of pollution in to the river during wet and dry periods ${ }^{10,11}$. However, there is currently no detailed understanding of the chemical concentrations and the level of contamination in Cauvery river. Keeping these views in mind a study has been conducted to evaluate the spatial distribution, seasonal variation of physicochemical concentration during February 2009 (post monsoon) and October 2009 (pre monsoon) in the river. Moreover, in order to maintain the quality of water, there is a need for regular monitoring and proper control of the water quality parameters. A study is made to evaluate the correlation and regression analysis techniques to interpret the missing parameters on a temporal basis. The missing water quality data from a spatial or temporal observation can pose a serious threat to data analysis, modeling studies and for forecasting purposes ${ }^{12}$. Hence, it is imperative to evaluate the missing observations based on complete and accurate data set.

\section{EXPERIMENTAL}

The Cauvery river originates at Talakaveri, Kodagu district, in the Western Ghats in the state of Karnataka and it enters Tamil Nadu through the Krishnagiri district. Three minor 
tributaries, the Palar, the Chennar and the Thoppar, enter the Cauvery on her course, above Stanley reservoir in Mettur, which further runs through Erode district where the Bhavani river merges with it. Bhavani, a major tributary of the Cauvery river rises in the Western ghats of Silent Valley National Park in Palakkad district of Kerala. Bhavani is more or less a perennial river fed mostly by the southwest monsoon and is also supplemented by the northeast monsoon. Bhavani river originates in the upper regions of the Nilgiris of the Western ghats. It descends towards west and flows through the attappady valley of Palakkad district in Kerala. Then it continues its path to the Nilgiri mountains through the districts of Nilgiris, Coimbatore and Erode.

While passing through Erode, two more tributaries namely Noyyal and the Amaravati join Cauvery river before it reaches the Tiruchirappalli district in Tamilnadu, India. The Noyyal rises from the Vellingiri hills in the Western ghats and is a tributary of river Cauvery. It receives its maximum rainfall during northeast monsoon. The Noyyal, is a seasonal river that has a peak flow only during monsoon and is merely a carrier of untreated sewage and industrial effluents from Coimbatore and Tirupur districts, the two main cities in its basin in the rest of the year. The $175 \mathrm{~km}$ long Amaravati river begins at the Kerala/Tamil Nadu border at the bottom of Manjampatti Valley between the Annamalai Hills and the Palni Hills. It descends in a northerly direction through Amaravathi reservoir and Amaravathi dam at Amaravathinagar. It joins with the Cauvery river at Thirumukkudal, about $10 \mathrm{~km}$ from Karur district. The Amaravathi river and its basin, especially in the vicinity of Karur, are heavily utilized for industrial processing water and waste disposal and have resulted in severe pollution due to large number of textile dyeing and bleaching units. The present study was conducted in 50 stations in a part of the river and its tributaries for a length of $100 \mathrm{Km}$ between the latitudes $11^{\circ} 29^{\prime} 35.1^{\prime \prime} \mathrm{N}$ and $10^{\circ} 57^{\prime} 24^{\prime \prime} \mathrm{N}$ and the longitudes $77^{\circ} 42^{\prime} 40.7^{\prime \prime} \mathrm{E}$ and $78^{\circ} 14^{\prime} 17.9^{\prime \prime} \mathrm{E}$.

Water samples were collected from 50 sites along the flow in Cauvery river and its tributaries during the months of February and October which represents pre monsoon and post monsoon period in 2009. Sites 7 to 11 were in Bhavani river located in the area of relatively low river pollution, sites 33 to 36 were in Noyyal river and sites 42 to 46 were in Amaravathi river which represents the zones of more pollution. Water samples were collected in polythene bottles, filtered and acidified to maintain a $\mathrm{pH}$ of 1 by adding one $\mathrm{mL}$ each of ultrapure nitric acid solution. During sampling, $\mathrm{pH}$, electrical conductivity and temperature were measured using portable meters. The samples were analyzed for determining its physiochemical characteristics in the laboratory using the standard methods recommended by the American Public Health Association ${ }^{13}$. Regression analysis is one of the many techniques for modeling and analyzing several variables, when there is relationship between a dependent variable and one or more independent variables. Regression model structure was adopted in the present study to estimate the missing water quality parameters on a temporal basis in the Cauvery river.

\section{RESULTS AND DISCUSSION}

The results of various physico chemical parameters in the sites during premonsoon and post monsoon periods along the river course under study are given in Table-1. Temporal variations were high in the surface water quality parameters, which can be observed from the high standard deviations. This is an indication of variation in the chemical constituents that may be contributed by point or non point sources and/or climatic factors ${ }^{14}$.

In Bhavani river, the $\mathrm{pH}$ was neutral and the water quality parameters were well within the permissible limits for drinking in all the samples. This situation implies that agricultural runoff is less significant in affecting the water quality in Bhavani river.

In Noyyal river, the $\mathrm{pH}$ is highly alkaline and the concentration of almost all the major ions, particularly TDS, hardness, $\mathrm{Cl}, \mathrm{Na}$ and $\mathrm{SO}_{4}$ is exceeding the permissible standards. The parameters were higher in the upstream side and showed a decreasing trend along the direction of flow towards Cauvery. This indicates strong additions of waste discharges from the industries located along the banks of the river near the sampling

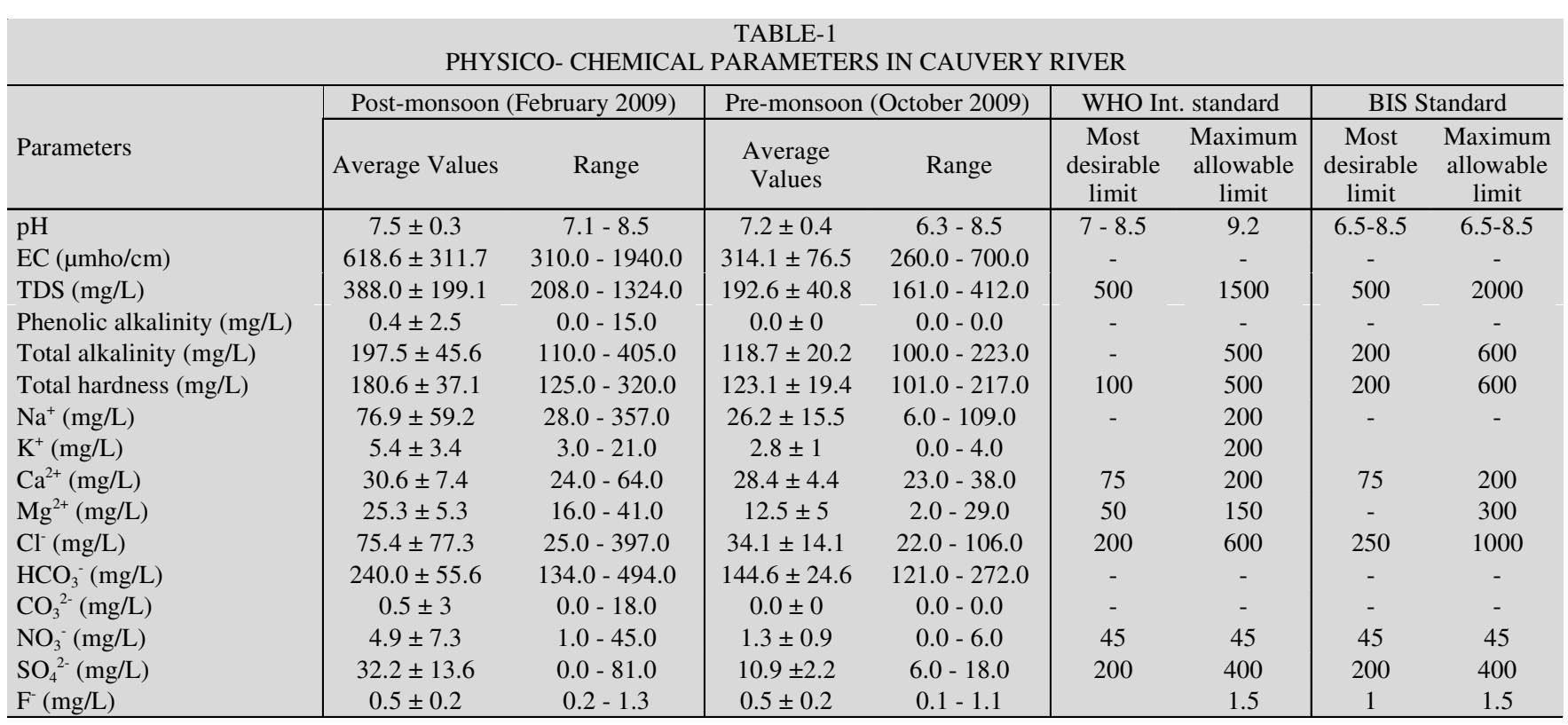


sites. Similarly, the values of TDS, $\mathrm{Na}$ and $\mathrm{Cl}$ were considerably higher during October than February in all the sites in Noyyal river.

The $\mathrm{pH}$ showed neutral to alkaline values in Amaravathi river. The water quality parameters namely TDS, EC, Cl, Na and $\mathrm{HCO}_{3}$ showed an increase in the samples from the sites along the direction of flow up to Pasupathipalayam (site 44) and are found to decrease in their values till the confluence of the river with Cauvery. The concentrations of the parameters showed higher values exceeding the permissible standards in October compared to February in Amaravathi which were very nearer to the permissible standards. No flow was observed in two sites during October and the high concentrations in samples of rest of the sites may be attributed to the failure of monsoon but with continuous industrial discharges. Pasupathipalayam (site 44) showed very high values of TDS, $\mathrm{Na}$ and $\mathrm{Cl}$ in both the periods and higher values of TDS, $\mathrm{Na}$ and $\mathrm{Cl}$ were observed in Karur (site 43) during October which supports the detrimental effects of industrial discharges into the river

The $\mathrm{pH}$ of surface water in the Cauvery river depicts neutral to alkaline values with an average of 7.2. The mean values of TDS, hardness and almost all other ions were higher during premonsoon period and the parameters were found to get diluted in the post monsoon period due to increased discharge from the Mettur reservoir in the upstream side and showed a relatively lesser concentration in Cauvery river. The water quality was good in the samples taken before and after the confluence of Bhavani river with Cauvery for a considerable length of the river in the downstream side with the exception of high TDS in Vairapalayam (site 19) which is near the municipal solid waste dumping yard in Erode district. The water quality parameters showed an increase in three samples taken after the confluence of Noyyal River with Cauvery which may be due to the addition of pollutants from the Noyyal followed with a decreasing trend thereafter. Similar trend was observed in Kattalai Kooduthurai (Site 47) which is the confluence point of Amaravathi river with Cauvery river with high levels of TDS, $\mathrm{Na}$ and $\mathrm{Cl}$. The samples in the downstream of Cauvery showed lesser values for the concentration of these parameters. These variations indicate the impacts of waste discharges in to the river course and the influence of water pollution from its tributaries ${ }^{15}$.

The parameters determined in the two seasons for the water quality analysis were evaluated by the box and Whiskers plot and is represented in Fig. 1. The box and Whiskers plot was used to study the trend and variation of the water quality
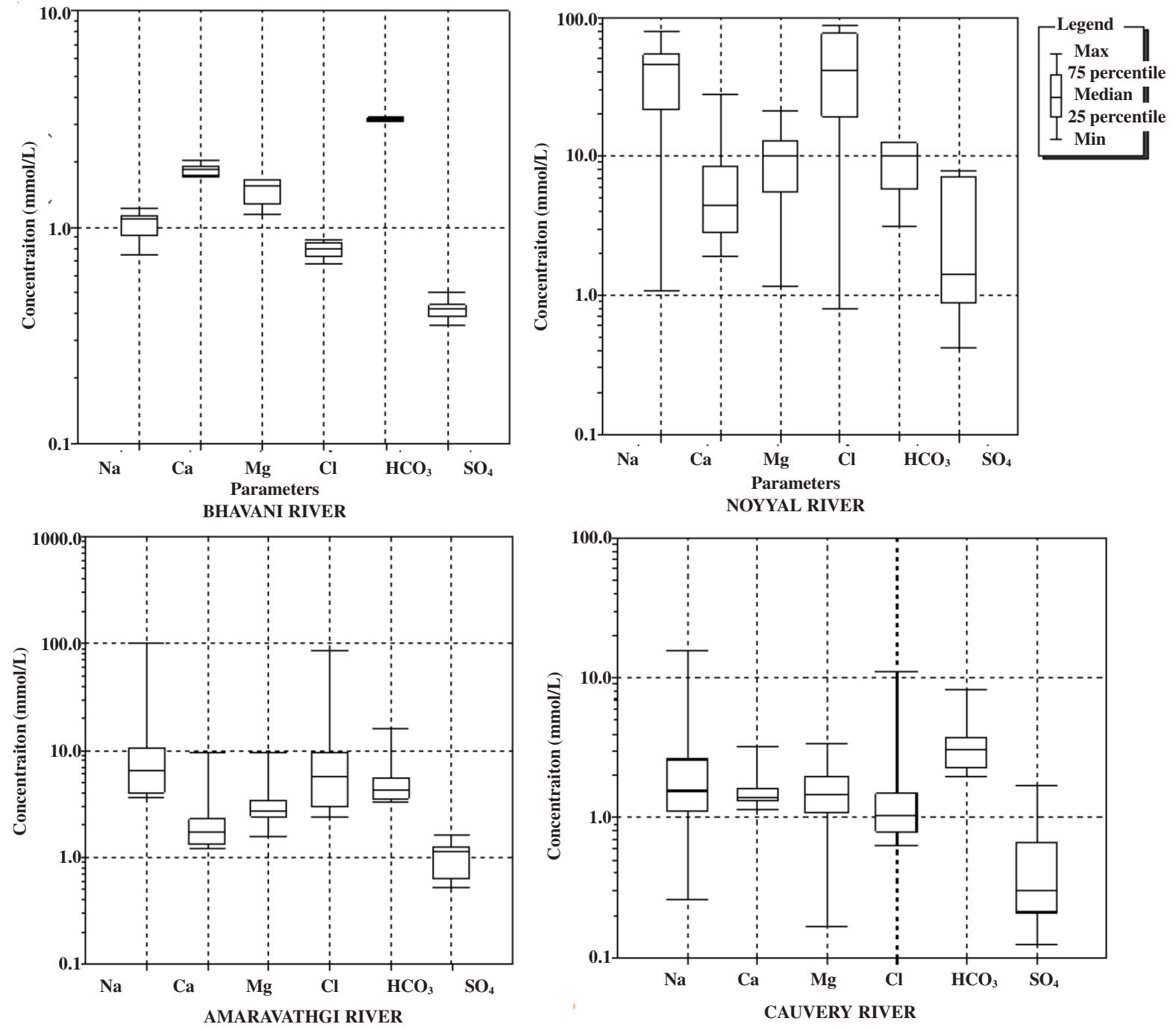

Fig. 1. Box and Whisker plot of the water quality parameters 
parameters among different sites during the two seasons. The criteria selected were concentration and water quality parameters. In Bhavani river, the scores distribution followed the sequence $\mathrm{Ca}<\mathrm{SO}_{4}<\mathrm{Mg}<\mathrm{Cl}<\mathrm{Na}<\mathrm{HCO}_{3}$, which shows that the water quality was most influenced by $\mathrm{HCO}_{3}$ whereas in Noyyal river, it was comparatively least predominant which predicted the following sequence $\mathrm{HCO}_{3}<\mathrm{Mg}<\mathrm{SO}_{4}<\mathrm{Ca}<$ $\mathrm{Na}<\mathrm{Cl}$. In Amaravathi river the scores distribution was in the order $\mathrm{SO}_{4}<\mathrm{Mg}<\mathrm{Ca}<\mathrm{HCO}_{3}<\mathrm{Na}<\mathrm{Cl}$ and in Cauvery, it depicted the sequence $\mathrm{Mg}<\mathrm{Ca}<\mathrm{SO}_{4}<\mathrm{HCO}_{3}<\mathrm{Cl}<\mathrm{Na}$. Thus, the water quality is found to be most influenced by the parameters $\mathrm{Na}$ and $\mathrm{Cl}$ in all the rivers and $\mathrm{Mg}, \mathrm{Ca}$ and $\mathrm{SO}_{4}$ was least significant. These elements probably show the result of mineral water reactions in the area with clear variations in their concentrations in each site with higher values at Vairapalayam in Cauvery ${ }^{16}$. $\mathrm{Na}$ is one of the most abundant elements on earth and is highly soluble. Increased concentration may be indicators of pollution from point source discharges such as waste water effluents ${ }^{17} . \mathrm{Cl}$ is likely to be resulted from dispersion of sewage discharges and is associated with industrial and agricultural runoff ${ }^{18,19}$. Ca and $\mathrm{Mg}$ may be due to weathering of rocks and $\mathrm{SO}_{4}$ arises from leaching of sedimentary rocks and may also be added from atmospheric precipitation ${ }^{20}$.
Various water quality parameters of the water samples collected from Cauvery river were checked for correlation (Tables 2 and 3). It has been observed that from the correlation studies, TDS showed a high positive correlation with total alkalinity, $\mathrm{Ca}, \mathrm{Mg}, \mathrm{Na}, \mathrm{K}$ and $\mathrm{Cl}$ in both the months. Sodium showed a positive correlation with $\mathrm{K}$ and $\mathrm{Cl}$ whereas $\mathrm{Mg}$ was highly correlated with hardness during February. Comparatively, the cations and anions showed strong positive correlations during October than during February. Calcium had a strong positive correlation with $\mathrm{Mg}, \mathrm{Na}$ and $\mathrm{K}$, whereas carbonates showed a positive correlation with TDS, $\mathrm{Mg}, \mathrm{Na}, \mathrm{Cl}$ and $\mathrm{SO}_{4}$ in October which was mode-rately weak during February. The greater the numerical value of correlation coefficient between the variables, the greater is the linear relationship between them.

Regression analysis helps to understand the typical variation of the dependent variable when any one of the independent variables is varied, while the other independent variables are held fixed. The parameters which had correlation coefficient more than 0.603 have been utilized to develop regression equations. In this study, Regression equations are generated (Table-4) by Stepwise regression method using statistical package for social sciences ${ }^{21}$ (SPSS, 1995) to predict models for the

TABLE-2

CORRELATION MATRIX AMONG WATER QUALITY PARAMETERS IN CAUVERY RIVER DURING FEBRUARY 2009

\begin{tabular}{|c|c|c|c|c|c|c|c|c|c|c|c|c|c|c|c|}
\hline & $\mathrm{pH}$ & $\mathrm{EC}$ & $\mathrm{NO}_{3}^{-}$ & T-alk & $\mathrm{TH}$ & $\mathrm{Ca}^{2+}$ & $\mathrm{Mg}^{2+}$ & $\mathrm{Na}^{+}$ & $\mathrm{K}^{+}$ & $\mathrm{Cl}^{-}$ & $\mathrm{SO}_{4}^{2-}$ & $\mathrm{CO}_{3}^{2-}$ & $\mathrm{HCO}_{3}^{-}$ & $\mathrm{F}^{-}$ & $\mathrm{pH}$ \\
\hline $\mathrm{pH}$ & 1 & & & & & & & & & & & & & & \\
\hline $\mathrm{EC}$ & 0.067 & 1 & & & & & & & & & & & & & \\
\hline $\mathrm{NO}_{3}^{-}$ & -0.32 & $0.633^{* *}$ & $0.735^{* *}$ & 1 & & & & & & & & & & & \\
\hline T-alk & 0.008 & $0.853^{* *}$ & $0.880^{* *}$ & $0.683 * *$ & 1 & & & & & & & & & & \\
\hline TH & 0.096 & $0.932 * *$ & $0.923^{* *}$ & $0.573 * *$ & $0.908^{* *}$ & 1 & & & & & & & & & \\
\hline $\mathrm{Ca}^{2+}$ & -0.04 & $0.878^{* *}$ & $0.900^{* *}$ & $0.679 * *$ & $0.935^{* *}$ & $0.903 * *$ & 1 & & & & & & & & \\
\hline $\mathrm{Mg}^{2+}$ & 0.191 & $0.835^{* *}$ & $0.03^{* *}$ & $0.403^{*}$ & $0.749 * *$ & $0.934 * *$ & $0.690^{* *}$ & 1 & & & & & & & \\
\hline $\mathrm{Na}^{+}$ & 0.015 & $0.984 * *$ & $0.997 * *$ & $0.733 * *$ & $0.860 * *$ & $0.892 * *$ & $0.880^{* *}$ & $0.766^{* *}$ & 1 & & & & & & \\
\hline $\mathrm{K}^{+}$ & -0.01 & 0.960 ** & $0.973^{* *}$ & $0.731 * *$ & $0.798^{* *}$ & $0.874 * *$ & $0.854^{* *}$ & $0.760^{* *}$ & $0.971 * *$ & 1 & & & & & \\
\hline $\mathrm{Cl}^{-}$ & 0.059 & $0.988 * *$ & $0.976^{* *}$ & $0.628 * *$ & $0.775^{* *}$ & $0.880 * *$ & $0.822^{* *}$ & $0.796^{* *}$ & $0.980^{* *}$ & $0.968^{* *}$ & 1 & & & & \\
\hline $\mathrm{SO}_{4}^{2-}$ & $0.487 * *$ & 0.266 & 0.161 & $-0.483 * *$ & 0.061 & 0.329 & 0.118 & $0.456^{* *}$ & 0.144 & 0.133 & 0.26 & 1 & & & \\
\hline $\mathrm{CO}_{3}^{2-}$ & $0.630^{* *}$ & 0.078 & 0.058 & -0.068 & 0.047 & 0.09 & 0.032 & 0.118 & 0.058 & 0.08 & 0.068 & 0.187 & 1 & & \\
\hline $\mathrm{HCO}_{3}^{-}$ & -0.06 & $0.844 * *$ & $0.873^{* *}$ & $0.690 * *$ & $0.994 * *$ & $0.897 * *$ & $0.930^{* *}$ & $0.736^{* *}$ & $0.853^{* *}$ & $0.788^{* *}$ & $0.768^{* *}$ & 0.04 & -0.062 & 1 & \\
\hline$F^{-}$ & $0.483 * *$ & $0.548 * *$ & $0.469 * *$ & -0.056 & $0.364 *$ & $0.525^{* *}$ & 0.327 & $0.603 * *$ & $0.470 * *$ & $0.406^{*}$ & $0.534 * *$ & $0.658 * *$ & 0.279 & $0.335^{*}$ & 1 \\
\hline
\end{tabular}

**Correlation is significant at the 0.01 level (2-tailed); *Correlation is significant at the 0.05 level (2-tailed); $\mathrm{TH}=$ Total hardness.

TABLE- 3

CORRELATION MATRIX AMONG WATER QUALITY PARAMETERS IN CAUVERY RIVER DURING OCTOBER 2009

\begin{tabular}{|c|c|c|c|c|c|c|c|c|c|c|c|c|c|c|}
\hline & $\mathrm{pH}$ & $\mathrm{EC}$ & $\mathrm{NO}_{3}^{-}$ & T-alk & $\mathrm{TH}$ & $\mathrm{Ca}^{2+}$ & $\mathrm{Mg}^{2+}$ & $\mathrm{Na}^{+}$ & $\mathrm{K}^{+}$ & $\mathrm{Cl}^{-}$ & $\mathrm{SO}_{4}^{2-}$ & $\mathrm{CO}_{3}{ }^{2-}$ & $\mathrm{HCO}_{3}^{-}$ & $\mathrm{F}^{-}$ \\
\hline $\mathrm{pH}$ & 1 & & & & & & & & & & & & & \\
\hline $\mathrm{EC}$ & $.730 * *$ & 1 & & & & & & & & & & & & \\
\hline $\mathrm{NO}_{3}^{-}$ & -0.04 & $.332 *$ & 1 & & & & & & & & & & & \\
\hline T-alk & $.716^{* *}$ & $.961 * *$ & $.431^{* *}$ & 1 & & & & & & & & & & \\
\hline $\mathrm{TH}$ & $.739 * *$ & $.994 * *$ & $.330^{*}$ & $.975 * *$ & 1 & & & & & & & & & \\
\hline $\mathrm{Ca}^{2+}$ & $.650 * *$ & $.956 * *$ & $.464 * *$ & $.981 * *$ & $.966 * *$ & 1 & & & & & & & & \\
\hline $\mathrm{Mg}^{2+}$ & $.758 * *$ & $.992 * *$ & 0.278 & $.957 * *$ & $.996 * *$ & $.938 * *$ & 1 & & & & & & & \\
\hline $\mathrm{Na}^{+}$ & $.719 * *$ & $.998 * *$ & $.349 *$ & $.956 * *$ & $.990 * *$ & $.951 * *$ & $.988 * *$ & 1 & & & & & & \\
\hline $\mathrm{K}^{+}$ & $.708 * *$ & $.986 * *$ & $.419 * *$ & $.958 * *$ & $.979 * *$ & $.963 * *$ & $.969 * *$ & $.982 * *$ & 1 & & & & & \\
\hline $\mathrm{Cl}^{-}$ & $.721 * *$ & $.998 * *$ & $.321^{*}$ & $.946^{* *}$ & $.989 * *$ & $.943 * *$ & $.989 * *$ & $.999 * *$ & $.980 * *$ & 1 & & & & \\
\hline $\mathrm{SO}_{4}^{2-}$ & $.766 * *$ & $.975 * *$ & 0.155 & $.908 * *$ & $.971 * *$ & $.892 * *$ & $.983 * *$ & $.975^{* *}$ & $.937 * *$ & $.980 * *$ & 1 & & & \\
\hline $\mathrm{CO}_{3}^{2-}$ & $.764 * *$ & $.932 * *$ & 0.203 & $.869 * *$ & $.927 * *$ & $.848 * *$ & $.940 * *$ & $.935^{* *}$ & $.893 * *$ & $.937 * *$ & $.950 * *$ & 1 & & \\
\hline $\mathrm{HCO}_{3}^{-}$ & $.677 * *$ & $.931 * *$ & $.469 * *$ & $.993 * *$ & $.949 * *$ & $.975 * *$ & $.924 * *$ & $.925 * *$ & $.937 * *$ & $.912^{* *}$ & $.862 * *$ & $.803^{* *}$ & 1 & \\
\hline $\mathrm{F}$ & $.801 * *$ & $.749 * *$ & 0.056 & $.732 * *$ & $.753 * *$ & $.709 * *$ & $.754 * *$ & $.727 * *$ & $.766^{* * *}$ & $.733 * *$ & $.738 * *$ & $.657^{* *}$ & $.722 * *$ & 1 \\
\hline
\end{tabular}


TABLE- 4

REGRESSION MODELS OF THE MAJOR IONS IN CAUVERY RIVER

\begin{tabular}{llcccc}
\hline Parameters & Stepwise Regression Equations & R Square & Std Error & Observed Values (mg/L) & Predicted Values (mg/L) \\
\hline $\mathrm{Na}$ & $0.296 \mathrm{TDS}-38.135$ & 0.993 & 4.497 & 109.12 & 4.50 \\
$\mathrm{~K}$ & 0.017 TDS -0.999 & 0.946 & 0.796 & 38.82 & 6.00 \\
$\mathrm{Ca}$ & $0.152 \mathrm{TA}+0.637$ & 0.935 & 2.669 & 34.53 & 29.00 \\
$\mathrm{Mg}$ & $0.134 \mathrm{TH}+1.185$ & 0.934 & 1.93 & 106 & 272.01 \\
$\mathrm{Cl}$ & $0.245 \mathrm{EC}-76.29$ & 0.977 & 11.959 & 0 & 0.26 \\
$\mathrm{HCO}_{3}$ & $1.213 \mathrm{TA}+0.511$ & 0.994 & 6.10 & 0.0 & 0 \\
$\mathrm{CO}_{3}$ & $1.2 \mathrm{PA}$ & 1 & 6.05 & 18.00 \\
$\mathrm{SO}_{4}$ & $3.424 \mathrm{pH}-2.334 \mathrm{NO}_{3}$ & 0.818 & & 15.1 \\
\hline
\end{tabular}

variables $\mathrm{Ca}, \mathrm{Mg}, \mathrm{Na}, \mathrm{K}, \mathrm{Cl}$ and $\mathrm{SO}_{4}$ by applying the variables TDS, EC, $\mathrm{pH}, \mathrm{NO}_{3}$, total alkalinity and total hardness as independent variables $\left(\mathrm{R}^{2}>82 \%\right)$. The equations were applied to predict the values of those parameters with the observed results and are found to be nearer to the observed results and their average values are given for the Cauvery river (Table-4). Thus, these equations would find use in determining the values of major and minor ions by knowing the values of above independent variables in the river stretch on a temporal basis.

\section{Conclusion}

The results of this study reveal that the water quality in the river Cauvery is influenced by industrial discharges and anthropogenic activities. The seasonal variations in water quality were imparted due to characteristics of the catchment and seasonal effects along with waste water discharges. The spatial analysis showed that the sites mostly affected were near the industries and the solid waste disposal region. This was significant from the results of water quality from the samples taken in Noyyal and Amaravathi rivers and that has impacted the quality of water in Cauvery for a considerable length. Sodium and chloride were observed to be the important parameters having strong variations in their concentration along the flow in the study area. The regression equations approve its usefulness in estimating the missing data for future studies. However, in both the seasons, the part of Cauvery river under study showed that most of the cations and anions are within the permissible standards except very few sites and can be used for domestic as well as industrial purposes. Nevertheless, there is a need for continuous monitoring and implementation of proper regulations for waste disposal thereby to improve the quality of the river.

\section{REFERENCES}

1. A. Mishra, A. Mukherjee and B.D. Tripathi, Int. J. Environ. Res., 3, 395 (2009).

2. R. Jindal and C. Sharma, Environ. Monit. Assess., 174, 417 (2011).
3. R.K. Trivedy, A.C. Shrotri and S.D. Khatavkar, in ed.: R.K. Trivedy, Physico-Chemical Characteristics and Phytoplankton of the River Panchganga Near Kolhapur, Maharashtra, Rivers of India, New Delhi: Ashish Publishing House (1990).

4. I.S. Eneji, R. Sha'Ato and P.A. Annune, Environ. Monit. Assess., 184, 201 (2012).

5. $\quad$ N. Raj and P.A. Azeez, Current Sci., 96, 2 (2009).

6. P. Dhanapakiam, V. Sampoorani and R. Kavitha, J. Environ. Biol., 20, 347 (1999).

7. K. Govindarajalu, in eds.: M.J. Bunch, V.M. Suresh and T.V. Kumaran, Industrial Effluent And Health Status - A Case Study of Noyyal River Basin, Proceedings of the Third International Conference on Environment and Health, Chennai, India, 15-17 December, 2003. Chennai: Department of Geography, University of Madras and Faculty of Environmental Studies, York University, pp. 150-157 (2003).

8. K. Usharani, K. Umarani, P.M. Ayyasamy, K. Shanthi and P. Lakshmanaperumalsamy, J. Appl. Sci. Environ. Manage., 14, 29 (2010).

9. J. Krishnaswamy, A. Baruah, N. Wickramasinghe and V. Srinivas, Beyond the Tsunami: Trends and Patterns in Hydrology and Water Quality in Coastal Ecosystems and Upstream Catchments in Tamil Nadu, India. UNDP/UNTRS, Chennai and ATREE, Bangalore, India, p. 62 (2008).

10. Y. Ouyang, P. Nkedi-Kizza, Q.T. Wu, D. Shinde and C.H. Huang, Water Res., 40, 3800 (2006).

11. P. Palma, P. Alvarenga, V.L. Palma, R.M. Fernandes, A.M.V.M. Soares and I.R. Barbosa, Environ. Monit. Assess., 165, 539 (2010).

12. Y.D. Ravichandran and K. Ramakrishnan, Asian J. Chem., 19, 2679 (2007).

13. APHA, Standard Methods for the Examination of Water and Waste water, Washington: American Public Health Association, edn. 21 (2005).

14. Sh. Najafpour, A.F.M. Alkarkhi, M.O.A. Kadir and Gh.D. Najafpour, Int. J. Environ. Res., 2, 349 (2008).

15. J.Z. Ma, Z.Y. Ding, G.X. Wei, H. Zhao and T.M. Huang, J. Environ. Manage., 90, 1168 (1996).

16. L. Belkhiri, A. Boudoukha and L. Mouni, Int. J. Environ. Res., 5, 537 (2011).

17. Y.-H. Yang, F. Zhou, H.-C. Guo, H. Sheng, H. Liu, X. Dao and C.-J. He, Environ. Monit. Assess., 170, 407 (2010).

18. C. Jerome and A. Pius, Am. J. Sci. Ind. Res., 1, 595 (2010).

19. S. Gholami and S. Srikantaswamy, World Appl. Sci. J., 6, 1157 (2009).

20. E. Yesilirmak and S. Anac, Asian J. Chem., 20, 2882 (2008).

21. SPSS (Statistical Package for Social Studies) version 6.1, USA. Professional Statistics 6.1, 385, Marija J. Norusis/SPSS Inc., Chicago (1995). 